\title{
Maritime litter studies in the Firth of Forth
}

\section{E. Caulton and M. Mocogni}

\section{Department of Biological Sciences, Napier College, Edinburgh, Scotland, U.K.}

During the past four years successive studies of litter have been undertaken on beaches along the southern shoreline of the Firth of Forth. The original and longest study was at Cramond, the subject of the poster display at this symposium. The Cramond study identified nineteen categories of litter, three of which were container and the rest non-container. Percentage composition of the major categories were: Containers $(18.8 \%)$, Plastic Sheeting $(18.8 \%)$, Clothing $(14.31 \%)$ and Plastic Fragments $(11.2 \%)$. Our findings revealed that the bulk of the litter of all categories was of local origin, deposited either directly onto the beach by visitors/local residents or indirectly by tidal distribution upstream from beach tips further east (e.g. at Granton). None of the Cramond litter was of foreign origin.

Subsequent studies along Edinburgh's coastline have been undertaken at Portobello, Seafield, Granton and Silverknowes. Only at the last named was any evidence of sea dumping found-some eight containers of foreign origin ranging from Scandinavia to the Mediterranean were recorded. A recent study carried out on litter on the two beaches at South Queensferry has revealed a sorry state with regard to this aspect of pollution. Results are currently being analysed and will be published in due course. Portobello beach would appear to be the cleanest of Edinburgh's coastline beaches. A weekly study of litter on the foreshore has been undertaken for some four months, the weekly analysis being carried out just before the daily round of the beach cleaning vehicle. Thus a twenty-four hour weekly sample has been recorded. These results are currently being analysed.

The conclusion reached to date would indicate the need for more publicity both on site and via the media to reinforce the desirable use of the already adequate litter disposal boxes/skips available to the public. Much money, equipment and labour is wasted on cleaning up litter-strewn beaches and such resources can and ought to be put to more essential tasks.

\section{Tributyltin contamination in the Firth of Forth}

\author{
S. K. Bailey \\ Napier College, Edinburgh, Scatland, U.K. \\ and
}

\section{M. Davies}

DAFS Marine Laboratory, P.O. Box 101, Victoria Road, Aberdeen AB9 8DB, Scotland, U.K.

Tributyltin (TBT) compounds are used as biocides in antifouling paints on marine structures, including the hulls of commercial and leisure craft. The TBT leaches slowly from the paint and prevents the settlement and growth of fouling organisms. Although TBT is rapidly degraded in sea water, the concentrations 
present in some areas have been shown to affect the growth and reproduction of marine organisms including phytoplankton, oysters, mussels and dogwhelks.

The effects on the dogwhelk Nucella lapillus can be used as an indication of TBT contamination, and are particularly useful in areas where TBT concentrations may be undetectable (i.e. less than $5 \mathrm{ng} / \mathrm{l}$ ) by routine water analysis methods. Exposure of female dogwhelks to TBT induces the development of certain male sexual characteristics, such as a penis and vas deferens. The condition (termed imposex) develops progressively (Gibbs \& Bryan 1986):-

Stage A Normal unaffected female

Stage B Penis and vas deferens development initiated

Stage C Penis enlarges, approaching that in the male; vas deferens complete

Stage D Large penis, vas deferens tissue proliferates and blocks the opening of the female reproductive tract, preventing release of egg capsules.

The degree of imposex is calculated as

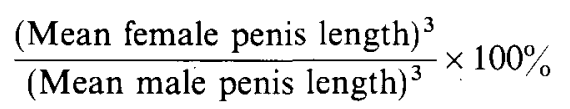

and may be used as an index of TBT contamination in coastal waters.

Adult dogwhelks from thirty-five localities in the Firth of Forth were examined between November 1986 and January 1987. The degree of imposex varied between background levels $(0-2 \%)$ and $109 \%$, and evidence of contamination by TBT was found throughout most of the Forth. Highest levels were found at

(a) Fishing harbours, e.g. Crail 64\%; Pittenweem 55\%; St Monance 35\%.

(b) Marinas, e.g. North Queensferry 33\%; South Queensferry 35\%; Kinghorn $37 \%$.

(c) Boatyards where vessels are scraped and re-painted, e.g. Cockenzie $109 \%$.

There are low degrees of imposex (8-15\%) around the oil rig construction and maintenance facilities in Largo Bay, which suggest insignificant inputs of TBT in this area.

Large proportions of unaffected or slightly affected females (Stage A, B) were only found in populations showing low degrees of imposex (e.g. $45 \%$ at Cambo Ness (East Fife) where imposex was $2 \%$ ). This proportion was much lower in areas of greater imposex development. The reproductive capacity of a population will be reduced when proliferation of vas deferens tissue blocks the genital papilla (Stage D) in a significant number of females. High proportions $(>25 \%)$ of such females were found in all populations with imposex of $>30 \%$, and some were regularly found at imposex levels of around $15 \%$.

The amount of TBT permitted in antifouling paints offered for retail sale is now controlled by the Control of Pollution Act (Antifouling Paint Regulations, 1986).

\section{Reference}

Gibbs, P. E. \& Bryan, G. W. 1986. Reproductive failure in populations of the dogwhelk Nucella lapillus caused by imposex induced by tributyltin from antifouling paints. Journal of the Marine Biological Association of the United Kingdom 66, 767-777. 